\title{
De unge og fremtidens ligestillingspolitik
}

\section{Af Ann-Dorte Christensen}

Ev der generationsforskelle $i$ holdningen til ligestilling $i$ dagens Danmark? Lagger de unge mand og kvinder vagt pai forskellige ting, nair de forbolder sig til ligestilling og lighed? Artiklen tager temperaturen på disse sporgsmål, og fremsatter forslag til, bvordan en fremtidig ligestillingsstrategi for de unge kunne se ud.

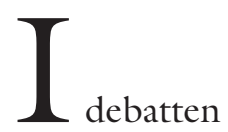

om den danske ligestillingspolitik dukker diskussionen om de unge kvinder og mænd jevnligt op, og der bliver ofte formuleret en modsætning mellem den nu midaldrendende fortrop af statsfeminister/"gamle rødstrømper" og nutidens unge kvinder, som har en anden relation til ligestilling og feminisme, end de unge kvinder havde for omkring 30 år siden.

Som i de andre diskussioner, der kører sideløbende - fx om mænds ligestilling, om forældremyndighedsspørgsmålet $\mathrm{og} \mathrm{om}$ brug af orlov til barsel og børnepasning så er debatten om de unge og ligestillingen i høj grad præget af skiftende debattørers subjektive erfaringer, holdninger og tolkninger. Det kan såmænd være udmærket, og dialogen er uden tvivl meget vigtig. Ind i mellem kan man dog savne facts og dokumentation bag synspunkterne, hvilket dog er svært, da der ikke findes særlig mange undersøgelser om disse spørgsmål i Dan- 
mark. Og særlig svært bliver det, når det drejer sig om holdninger, som både er vanskelige at undersøge og forklare.

Formålet med denne artikel er at indkredse de unges holdning til ligestilling og lighed i samfundet nærmere, bl.a. med det formål at komme med forslag til, hvordan en fremtidig ligestillingsstrategi for de unge kunne se ud. Jeg sammenfatter resultaterne af forskellige undersøgelser, som forholder sig til problemstillingen. Udgangspunktet er nogle af resultaterne fra den danske medborgerundersøgelse ${ }^{2}$, som giver mulighed for at sammenligne for det første de unge holdning til ligestilling med andre generationers. For det andet giver undersøgelsen mulighed for at sammenholde holdningen til ligestilling mellem kønnene med holdningen til de generelle lighedsidealer i samfundet.

Jeg lægger vægt på at synliggøre holdningsforskelle mellem de unge kvinder og de unge mænd, samt på de holdningsforskelle der måtte være mellem de unge og den såkaldte velfærdsgeneration, som ofte fremhæves banebrydende for kvindefrigørelse og ligestilling. Dette betyder ikke, at andre generationer og andre sociale differentieringer, som fx klasse og race ikke er relevante $\mathrm{i}$ forhold til ligestilling, tværtimod.

\section{GENERATIONER}

I medborgerundersøgelsen er der opstillet fire såkaldte sociologiske generationer. Dis- se generationsprofiler bygger på historiske kendetegn for den enkelte generation med vægt på lære- og erfaringsprocesserne i ungdomsårene.

Hovedvægten i dette oplæg ligger på de unge kvinder og mænd i 80'er-generationen. Sammenlignet med andre ungdomsundersøgelser, er de unge her forholdsvis gamle. Som regel plejer man at betegne især aldersgruppen 16-25 årige som de unge. Når jeg her har lagt snittet fra de 18-29 årige skyldes det for det første, at det rent statistisk er nødvendigt til at arbejde med en forholdsvis stor gruppe, når den også skal "halveres" på køn. Det andet - mere indholdsmæssige - argument er, at det rent metodisk er vanskeligt at undersøge politisk deltagelse og politiske holdninger gennem en spørgeskemaundersøgelse før respondenterne har en vis form for politiske erfaringer. ${ }^{3}$ En mere præcis betegnelse for ungdomsgruppen, jeg behandler her, kunne være de unge medborgere.

Pladsen tillader ikke en grundig præsentation af alle fire generationer (se evt. Johannes Andersen m.fl. 1993 og Ann-Dorte Christensen 1997). Jeg vil derfor nøjes med kort at præcisere de væsentligste forskelle mellem 80'er-generationen og velfærdsgenerationen, da netop forskellene mellem disse to generationer efter min mening er vigtig for også at forstå ligestillingspolitikken. Resten af artiklen fokuserer også specielt på forskelle og ensheder mellem disse to generationer.

Velfardsgenerationen, som er født mellem

BEFOLKNINGEN FORDELT PÅ GENERATIONER 1990 (N=1968)

\section{ALDER}

8 - 29 år

30 - 44 år

$45-59$ år

Efterkrigsgeneration

Krisegeneration over 60 år
FØDSELSAR

$1961-1972$

$1946-1960$

1931 - 1945

før 1931 
1946-1960, er interessant på to måder. For det første er det med denne generation, at ungdommen for alvor far en ny betydning og bliver en selvstændig livsfase med rum for skabelse af selvstændige kulturelle og politiske udtryksformer. For det andet er medlemmerne i denne generation mere end i nogen anden generation "børn af velfærdsstaten". De er som børn og unge vokset op i en tid med fuld beskxftigelse og et ideal om uddannelse til alle. Det gjorde det bl.a. muligt at bryde med den sociale arv i langt højere grad end tidligere. Generationen blev bærere af 68'er-mobiliseringen, af en ny ungdomskultur med protest mod "gamle" autoriteter og af nye visioner og eksperimenter både på den private og den politiske sfære. Det er også kvinderne i denne generation, der er gået forrest i kampen for kvindefrigørelse og ligestilling.

Hvis stikordene for velfardsgenerationen er frigørelse og kollektivitet er stikordene for 80'er-generationen modsetninger og individualitet. Det begrunder jeg med det generelle skift i tidsånden, der har været fra 60 'erne til 80'erne. Her er fx den offentlige omsorgsideologi blevet konfronteret med en borgerlig liberal ideologi om individuel succes. 80'er-generationen er ikke vokset op med velfærdsstatens succes, men i stedet i en fase, hvor arbejdsløshed og offentlige nedskæringer har præget den politiske dagsorden. Det fører ofte til grundlæggende modsætninger mellem på den ene side forventninger og idealer og på den anden side de praktiske og realiserbare muligheder: Alt er nu tilladt, men hvor meget er muligt? Det er altså dobbelthederne og tvetydighederne, jeg fremhæver som grundlæggende politiske socialiseringsfaktorer i 80'er-generationen (Johannes Andersen m.fl. 1993:157ff.).

Det er altså vigtigt at være opmærksom på, at rammerne omkring den politiske socialisering for 80 'er-generationen er grundlæggende anderledes, end den var for velfærdsgenerationen. Først og fremmest er 80 'er-generationen ikke er en mobiliseret generation. Det var velfærdsgenerationen, og det har ind imellem givet anledning til en forventning om, at "alle unge til enhver tid vil være mobiliseret", hvilket er en stor misforståelse. 4

\section{HOLDNINGEN TIL LIGESTILLING}

Der er ingen tvivl om, at ligestillingen mellem kønnene i dag er blevet en integreret del af lighedsmålsætningen i de nordiske lande. Tanken om lighed mellem kønnene er blevet et af de grundlæggende idealer, som de nordiske velfærdsstater hviler på. Ligestillingspolitikken er blevet institutionaliseret på en række områder i samfundet, Ligestillingsråd, ligestillingskonsulenter, ligestillingsudvalg mv. På den anden side ved vi også, at der for øjeblikket ikke er konsensus omkring ligestillingspolitikken - snarere er der tale om forskellige konkurrerende diskurser mellem forskellige grupper og aktører i samfundet. En central konfliktdimension går som bekendt mellem kvindeog mandeorganisationerne, $\mathrm{fx}$ i forhold til forældremyndighedsspørgsmålet. En anden konfliktdimension ser ud til at tegne sig mellem de forskellige (kvinde)generationer, hvilket for mig at se hænger sammen med, at både den konkrete oplevelse af relationen mellem kønnene og kønsdebatten har været grundlæggende forskellige for de forskellige generationer. Fx kan man have en tese om, at hvor velfærdsgenerationen har været en del af oprøret og en central del af de forhandlinger, der har fundet sted mellem mænd og kvinder i denne generation, er de unge i 80'erne mere "flasket op" med ligestillingen som en selvfølge, som noget, "der bare var der" og noget, som staten tog sig af.

I det følgende vil jeg præsentere to barometre på holdningen til ligestillingen i samfundet. For det første vil jeg belyse holdningen til kvindediskrimination, og for det andet LO-medlemmernes holdning til ligeløn.

Forventningen om, at de unge i mindre 


\section{TABEL 1 KVINDEDISKRIMINATION}

Andel af befolkningen, der mener, at kvinder i kommer i anden række i forhold til mænd. Pct.

$\operatorname{ALLE}(\mathrm{N}: 1968)$

Kvinder

74

Mænd

64

80'er-generationen

$\mathrm{K}$

78

(18-29 år)

$\mathrm{M}$

69

Velfærdsgenerationen

(30-44 år)

\section{K}

$\mathrm{M}$

60

Anm.: Tabellen er konstrueret ved at lægge kategorierne "ofte" og "af og til" sammen. Signifi-

kansniveauer: generation 0.000 ; køn 0.000 ; køn/80'er-generationen 0.048. (Der er signifikante kønsforskelle i velfærdsgenerationen, men ikke i efterkrigs- og krisegenerationen) ( $\mathrm{N}=1968)$.

Kilde: Ann-Dorte Christensen "Køn, ungdom og værdiopbrud", i: Andersen og Torpe (red.) Demokrati og politisk kultur. Herning: Forlaget Systime, side 194.

grad end de andre generationer mener, at der finder en diskrimination af kvinder sted holder ikke stik. I stedet viser tabel 1 , at der i befolkning generelt er en høj grad af enighed om, at kvinder kommer i anden række i forhold til mænd (ca. 70 procent). Det fremgår også, at det er blandt de unge, opfattelsen af kvindediskriminationen er mest udbredt, hvorimod den er mindre udbredt i de xldste generationer. Det er ikke overraskende, at flere kvinder end mænd svarer positivt, selv om det på den anden side må konstateres, at kønsforskellen er forholdsvis begrænset.

Det ser således ikke ud til, at de unge opfatter kvindediskriminationen som noget mødrene og formødrene fik overstået. Tværtimod er andelen af kvinder, der mener, der finder en diskrimination sted lige så stor i 80'er-generationen som i velfærdsgenerationen, der primært rummer den kvindepolitisk mobiliserede gruppe, som nogle af de unge kvinder i dag forsøger at finde et ståsted i forhold til.

Det er bemærkelsesværdigt, at kønsforskellen blandt de unge er langt mindre end i velfærdsgenerationen. Faktisk er det blandt mandene $i$ velfardsgenerationen, at opfattelsen af kvindediskriminationen er lavest. Det kan hænge sammen med, at det er denne generation af mænd, der i praksis har oplevet de største forandringer på dette område. Dertil kommer formentlig også mere subjektive vurderinger, som er påvirket af, at mændene i denne generation har haft kvindefrigørelse, ligestillingsdiskussioner og måske ligestillingspolitikken personligt meget txt inde på livet. Nogle af de aktuelle debatter mellem kvinde- og mandeorganisationerne om fremtidens ligestillingspolitik må efter min mening ses i dette perspektiv.

\section{LO-MEDLEMMERS HOLDNING TIL LIGELØN}

Spørgsmålet om ligeløn har altid stået centralt i forhold til ligestillingsdebatten. Kravet om ligeløn har været en central del af både den gamle og den nye kvindebevægelses krav. Og ligelønnen er da også gennem Ligelønsloven blevet en vigtig del af ligestillingsarbejdet i staten og det arbejdsmarkedspolitiske system. Men samtidig hermed er der klare tendenser til, at netop spørgsmålet om køn og løn er et område, hvor der fortsat er markant uligheder mellem kønnene.

Det er på det seneste dokumenteret i flere af Ligestillingsrådets publikationer. Fx viser Kvinder og Mænd (1995), at mænds gennemsnitlige indkomst er 75 procent højere end kvinders, og at timelønnen $\mathrm{fx}$ for ikke-faglærte arbejdere og funktionærer 
ser ud til at bevæge sig i retning af en større ulighed (i 1989 udgjorde kvindernes timeløn 89 procent af mændenes). I bogen Køn og Løn, som er et led i Ligestillingsrådets projekt Ligeløn, viser Lis Højgård at køn i sig selv ikke forklarer løngabet mellem kvinder og mænd. I stedet skabes lønforskellene $\mathrm{i}$ et samspil mellem følgende tre faktorer: et differentieret lønsystem, kønsarbejdsdelingen (som både kan være traditionel og nyetableret) samt traditionsbestemte kønsforestillinger (Lis Højgård 1996:220).

Medborgerundersøgelsen tager ikke spørgsmålet om ligeløn op. Til gengxld er det grundigt behandlet i en undersøgelse af de danske LO-medlemmers erfaringer, værdier og holdninger til fagforeningen, til arbejdspladsen og til staten. 5

Undersøgelsen viser, at der en meget stor opbakning bag kravet om ligeløn

\section{TABEL 2 : LigeL ØN}

Pct. andel af LO-medlemmer, der mener det er vigtigt at udligne lonforskelle mellem kvinder og mand.

$\begin{array}{ccc}\text { 80'er generationen } & \text { K } & 88 \\ & \text { M } & 77 \\ & & \\ \text { Velfxrdsgenerationen } & \text { K } & 93 \\ & \text { M } & 78\end{array}$

Anm: Særlige kørsler på APL-projektet. Der er anvendt vægtede data. Der er spurgt til fagforeningens vigtigste opgaver. Tabellen er konstrueret ved at lægge de, der erklærer sig helt og delvis enig i, at en af fagforeningens vigtigste opgaver er at udligne lønforskellene mellem mænd og kvinder. ( $\mathrm{N}=$ 3227)

Kilde: Ann-Dorte Christensen "Køn, ungdom og værdiopbrud", i: Andersen og Torpe (red.) Demokrati og politisk kultur. Herning: Forlaget Systime, side 204. blandt medlemmerne i LO. Således ser mellem 80 og 90 procent af medlemmerne det som en af fagbevægelsens vigtigste opgaver at udligne lønforskellene mellem kvinder og mænd. Der er en høj grad af enighed omkring kravet, dog med en svag tendens til, at ligelønnen anses for mere vigtig blandt kvinder end blandt mænd, og at ligelønnen prioriteres højere i de ældste generationer end i de yngste. Mest markant er kravet således blandt de to ældste kvindegenerationer, men som det fremgår af tabel 2 , er der også blandt de to yngste generationer en stor opbakning bag dette krav.

I APL-projektet er medlemmernes ønske om mere ligeløn sat i relation til andre vigtige opgaver i fagbevægelsen. Denne analyse viser, at forbedring af arbejdsmiljøet tillægges den største betydning, mens udligning af lønforskelle mellem kønnene kommer ind som en 2. prioritet (sammen med bekæmpelse af arbejdsløshed og tryghed i ansættelsen).

Det interessante i denne sammenhæng er, at spørgsmålet om solidarisk lønpolitik (altså udligningen af lønforskelle mellem højt og lavtuddannede) prioriteres betydeligt lavere (Henning Jørgensen m.fl. 1992:260). Umiddelbart kunne man forvente, at denne prioritering ville dække over store forskelle mellem forbundene afhængig af kønssammensætning og af forholdet mellem højt- og lavtuddannede. Men det er ikke tilfældet. Tværtimod viser det sig, at inden for samtlige forbund ser medlemmerne det som en vigtigere opgave at arbejde for ligeløn mellem kvinder og mænd end den solidariske lønpolitik. Det gælder således også de typiske mandeforbund som Metalarbejderforbundet, Туроgrafforbundet og Specialarbejderforbundet. Specielt overraskende er sidstnævnte, da Specialarbejderforbundet traditionelt har været den mest markante fortaler for den solidariske lønpolitik.

Opsamlende viser de to eksempler, at der generelt i samfundet er en opbakning bag de centrale dimensioner i ligestillingspoli- 
tikken. For det første er der en udbredt enighed i befolkningen på tværs af køn og generation om, at der finder en diskrimination af kvinder sted. For det andet understreger LO-medlemmernes klare signal om, at fagforeningen bør prioritere ligelønnen som et centralt område den betydning og spredning, der er sket af ligestillingspolitikken. De unges holdning til både den generelle kvindediskrimination og til ligelønnen ligger tæt på holdningen i de andre generationer. Man kan sige, at der er registreret en enighed omkring ligestillingspolitikkens nødvendighed, men ikke taget stilling til de politiske instrumenter, der skal bruges.

\section{POLITISKE VÆRDIER MED SÆRLIG FOKUS PÅ HOLDNINGEN TIL VELFÆRDSSTATEN}

Hvordan hænger holdningen til ligestillingen sammen med den generelle holdning til ligheden i samfundet? Det fremhæves ofte som et særligt kendetegn ved de nor-

Tabel 3: Holdninger til centrale VÆrdier i Velfærdsstaten. PCt. Andele

SOCIALE REFORMER (1)

Positiv Negativ Neutral

Alle $(\mathrm{N}=1968)$

Kvinder

Mænd

80'er-gen.

$\mathrm{K}$

71

21

$(-17)$

(18-29 år) M

(16)

63

27

36

10

38

Velfærds-gen. K

(4)

$(30-45$ år $) \quad M$
62
$(-4)$

31
8

8

SOCIAL TRYGHED (2)

Positiv Negativ Neutral

48

37

15

53

32

15

44

42

15

12

(29)

8

38

50

12

54

35

11

(3)

$(-1)$

$51 \quad 36$

(1) Respondenterne er blevet bedt om at tage stilling til flg. 2 udsagn:

A: $\quad$ Man er gået for langt med sociale reformer her i landet. Folk burde mere end nu klare sig uden sociale sikringer og bidrag fra samfundet.

B: De sociale reformer, som er gennemført i vort land, bør opretholdes i mindst samme omfang som nu.

(2) Respondenterne er blevet bedt om at erklære sig enige/uenige i flg. udsagn:

I fremtiden bør den enkelte i højere grad klare sig uden offentlig støtte, også selv om det kan medføre større sociale forskelle.

Kilde: Ann-Dorte Christensen, "Køn, ungdom og værdiopbrud", i: Johannes Andersen og Lars Torpe (red.), Demokrati og politisk kultur. Et rids af et demokratisk medborgerskab, Herning: Systime 1994, p. 187 og 188 . 
diske velfærdsstater, at ligheden mellem kønnene er blevet institutionaliseret og en del af det generelle lighedsideal, som samfundet er bygget op omkring. Det er derfor naturligt at forvente, at den konsensus, der tilsyneladende er omkring holdningen til ligestillingen mellem kønnene også slår igennem i holdningen til den generelle lighed i samfundet. Denne problematik vil jeg i det følgende belyse med særlig fokus på holdningen til centrale værdier i velfærdsstaten.

Tabel 3 viser forskellene $i$ kvinder og mænds holdninger til to af velfærdsstatens kerneområder, nemlig sociale reformer og social tryghed, opgjort på de fire generationer. Tabellen viser, at kvinder generelt er lidt mere positive over for velfærdsstaten end mænd. Det gælder også for de to ældste generationer, som ellers er kendetegnet af, at kvinder er lidt mere højreorienteret end mænd. Tabellen viser også, at der i velferdsgenerationen er en forholdsvis stor enighed mellem kønnene i holdningen til velfærdsstaten. Hvor der i denne generation var den største kønsforskel i holdningen til kvindediskriminationen, er det også denne generation, der udtrykker den største konsensus bag de sociale reformer og den sociale tryghed.

Men sådan er det ikke blandt de unge i 80 'er-generationen. Hvor de unge kvinder markerer sig som den mest fremtrædende fortalere for sociale reformer og social tryghed, markerer de unge mænd sig som de mest kritiske af alle mandegenerationer. Snareve end konsensus er der altså tale om en markant polarisering blandt de unge $i$ holdningen til velferdsstaten.

Kønspolariseringen blandt de unge kvinder og mænd begrænser sig ikke til de to barometre, der er målt på her. Den går igen på en række andre spørgsmål, der vedrører velfærdsstaten og den offentlige sektor, hvor de unge mænd fx udviser en langt større opbakning end de unge kvinder til privatisering og til brugerbetaling. $\mathrm{Og}$ kønspolariseringen afspejler sig derudover også i den generelle værdiorientering, hvor de unge mænd er langt mere højreorienterede og materialistisk indstillede end de unge kvinder. Dette manifesterer sig også konkret i partivalget, hvor de unge mænd udviser en forholdsvis stor opbakning bag partiet Venstre (22 procent), mens næsten en fjerdedel af de unge kvinder ikke er afklaret på partivalget (Ann-Dorte Christensen 1994:190).

Hvor der som tidligere vist er en høj grad af konsensus omkring ligestillingspolitikkens nødvendighed på tværs af køn og på tværs af generationer er det ikke tilfældet i forhold til den generelle lighed i samfundet. Set i forhold til kønsforskellene i de forskellige generationer er det især vigtigt at fremhæve forskellene mellem velfærdsgenerationen og 80'er-generationen.

Hvad angår velferdsgenerationen er det den generation af alle, hvor kønsforskellene er lavest både $\mathrm{i}$ forhold til holdningen til velfærdsstaten og i den generelle værdiorientering. I denne generation kan man mere end $\mathrm{i}$ andre generationer tale om politisk konsensus mellem mænd og kvinder. Det er derfor overraskende, at dette ikke omfatter holdningen til, hvorvidt der finder en diskrimination af kvinder sted. Mindre end de unge - meget ny-liberale unge mænd er mændene i velfærdsgenerationen enige i, at der finder en kvindediskrimination sted. Som nævnt tidligere hænger dette givetvis sammen med både fælles og individuelle oplevelser af reelle ændringer mellem kønnene, som især har været båret af denne generation.

Hvad angår 80-generationen er der ikke tale om enighed mellem kønnene i forhold til velfærdsstatens grundlæggende værdier, men i stedet om en markant holdningspolarisering. Det rejser nogle tankevækkende perspektiver for fremtiden. For hvis de unge i 80'er-generationen fastholder den nuværende politiske værdiorientering tyder det på, at vi bevæger os i retning af (nye) kønspolariseringer, der udspiller sig om- 
kring en individualisme-kollektivisme akse. I den ene pol har vi de unge mænd, der udtrykker en individualistisk og markedsorienteret holdning - i den anden pol de unge kvinder, der støtter kraftigt op omkring en fælles offentligt omsorgsorientering (Christensen 1994). Samtidig hermed er det tankevækkende, at den markante konfliktlinje mellem kønnene i forhold til de generelle lighedsdimensioner i samfundet ikke slår igennem i holdningen til kvindediskriminationen. Det er dog et åbent spørgsmål, om denne konsensus vil kunne bevares i det øjeblik, der tales om iværksættelse af konkrete politikker til at afhjælpe kvindediskriminationen. Det er sandsynligt at forvente, at de unge mænds ny-liberale orientering vil markere sig som afstandtagen til statslig indgriben og reguleringer $\mathrm{i}$ forhold til kønsuligheder.

\section{FORKLARINGER PÅ POLARISERINGEN MELLEM DE UNGE KVINDER OG MÆND}

Hvordan skal man tolke denne markante kønspolarisering blandt de unge? Og hvad betyder den for relationen mellem kønnene i fremtiden? Det er nogle af de spørgsmål, jeg i det følgende vil komme med nogle bud på. En nærmere forståelse af forskellene er relevante $\mathrm{i}$ forhold til en konkretisering af en ligestillingspolitik, der kan rumme kønsforskellenes forskellige betydning og udtryksformer i de fire generationer. I dag er forståelsen af kønsrelationerne i familierne, på arbejdsmarkedet og i politikken i høj grad præget af velfærdsgenerationen - af den livsfase denne generation befinder sig i og af den særlige betydning som køn har for denne generation. Vi er dog på vej mod et generationsskifte, hvor værdierne og relationen mellem kønnene blandt de unge kommer til at spille en stigende rolle. Og der er ingen grund til at tro, at de blot “overtager" velfærdsgenerationens "projekter” - heller ikke på ligestillingsområdet!

\section{DET MODERNE SAMFUND}

Det er en grundlrggende antagelse, at der med det moderne samfund følger en stigende individualisering og kulturel frisettelse af individerne. Det betyder, at tilværelsen nu i langt højere grad end tidligere er op til det enkelte individs egne valg. I tidligere generationer var tilværelsen som regel bestemt af, hvilket køn man havde, og hvilken klasse man kom fra. Man fik ofte den samme sociale status og de samme livsbaner som ens forældre, afhængigt af køn. Ifølge teorierne om det sen-moderne samfund er man i dag mere "frisat" til selv at vælge på en lang række centrale områder. Man er på den led selv blevet kernen i sit eget livsprojekt. ${ }^{6}$

Værdierne er i opbrud, og de har mistet deres faste forankring ( $\mathrm{fx}$ i forhold til klasse). Man vælger "frit", hvor man den ene dag kan være individualist og den anden kollektivist. Frigørelsen fra de traditionelle tolkningsmønstre ( $\mathrm{fx}$ familien) betyder, at fokus i langt højere grad er blevet den enkelte. Givet alle muligheder, der står åbne, er man selv ansvarlig for at bruge dem på de relevante livsområder. Hvor problemet tidligere ofte var "jeg vil for meget" er det nu blevet til "jeg opnår for lidt" .

Dette værdiopbrud og den kulturelle frisættelse udgør en central ramme omkring de unge kvinder og mænds livsprojekter og tanker om fremtiden, fordi de er den af de fire generationer, der er mest omfattet af modernitetens konsekvenser. Det er derfor tankevækkende, at resultaterne af medborgerundersøgelsen viser, at de unge kvinder og mænd holdningsmæssigt bevæger sig i hver sin retning. Det rejser det grundlæggende spørgsmål: Hvordan kan det vere, at vi blandt de unge finder en så markant kønspolarisering, nar de samtidig er den generation af alle generationer, hoor kvinders og mands muligheder (for uddannelse og erhvervsarbejde $f x$ ) har veret mest lige?

En mulig tolkning på kønspolariseringen blandt de unge er, at de unge mænd mere end de unge kvinder "spiller op" til det 
moderne. De lægger op til et opgør med velfærdsstatens "formynderi" og ønsker i stedet mere autonomi og mere individuel selvudfoldelse. Set i det perspektiv kan man også argumentere for, at de unge kvinder holder mere fast i konventionerne. De udtrykker med andre ord angst for fornyelse og detraditionalisering. Men hvorfor føler de unge mænd sig tiltrukket af de ny-liberale tendenser og individualiseringen på markedet, mens de unge kvinder holder fast i velfærdsstaten og det kollektive ansvar?

Fyldestgørende forklaringer herfor skal efter min mening ikke kun findes i forståelsen af det moderne samfund. Spørgsmålet er nemlig, om de unges valg er så "frie", som denne tankegang lægger op til. Og dernæst: om denne frihed har den samme betydning for de unge kvinder og de unge mænd? Min tese er, at den politiske verdiorientering - bàde hvad angàr ligestillingen og den generelle lighedsdimension $i$ samfundet fortsat har en forholdsvis stabil social forankring. På den led er der ikke kun tale om "frie valg", men også som sociale realiteter, der har en strukturerende betydning. Brugbare muligheder - og prioriteringen af disse - hænger stadig væk sammen med den placering man har i samfundet. Og denne placering afhænger bl.a. af køn, i og med at uligheden mellem kønnene (sammen med fx den sociale ulighed) hører til en af de centrale strukturerende faktorer. Både direkte og indirekte spiller dette formentlig en rolle for de unge kvinders politiske værdidannelse.

Mere end nogen anden generation er de unge i dag vokset op med en forventning om, at kvinder og mænd har de samme muligheder. En forventning, der er blevet stadfestet som en rettighed gennem ligestillingspolitikken. Og en forventning, som fx uddannelsessystemet har været med til at bekræfte i praksis. Men på en række områder har den sociale realitet været en anden - forventningen om lighed mellem kvinder og mænd er ikke blevet omsat til brugbare muligheder, især ikke på arbejdsmarkedet.

De unge kvinders massive opbakning bag velfærdsstaten kan forstås inden for rammerne af dette skisma mellem forventninger og muligheder. I stedet for troen på de "frie" muligheder kan staten fungere som et sikkerhedsnet og en brugbar mulighed. Det tyder på, at dette gxlder i mindst lige så høj grad i forhold til en sikring af sociale rettigheder og tryghed som i forhold til ligestillingspolitikken. Det ser således ud til, at de unge kvinder betragter velfærdsstaten som en nodvendig forudsetning for opnående af autonomi og individualisering. Omvendt tyder det på, at autonomi og frihed for de unge mænd er forbundet med selvudfoldelsesmulighederne på markedet, mens velfærdsstaten ses som en formynderisk barriere.

\section{STRATEGIER I DET FREMTIDIGE LIGESTILLINGSARBEJDE}

Når man tænker de unge ind i fremtidens ligestillingspolitik er det vigtig at være opmærksom på, at der i gruppen af unge er to grundlæggende tendenser, som har betydning for ligestilling og kønsidentitet. De to tendenser er ikke skarpt adskilte - de fungerer side om side og er ofte overlappende. Der er på den ene side en tendens til, at de unge for at opbygge deres kønsidentitet og kvinde- og manderoller lægger stor vægt på at markere kønsforskelle. Fremhævelse af de kvindelige og mandlige sider indgår som en væsentlig del af det sociale orienteringsmønster især blandt de helt unge fx mellem 15-20 år. På den anden side er det også mens man er ung, man konkret oplever uligestillingen mellem kønnene. Man vil typisk erfare, at køn betyder noget, når man søger sit første job, eller får sit første barn. Denne tendens vil være mest fremtrædende blandt gruppen af lidt ældre unge, som er begyndt at etablere et arbejds- og familieliv.

Kønsidentiteten og opfattelsen af hvorvidt ligestillingsperspektiverne har relevans 
for den enkelte er meget forskellige for de to grupper af unge - så forskellige, at jeg vil hævde, at man politisk kan komme til at handle modsat intentionerne ved ikke at være opmærksom på forskellene. Kønnets betydning blandt de unge i dag aktualiserer den klassiske tankegang om, at være forskellige, men lige.

Min grundleggende tese er, at hvor den forste gruppe af unge $i$ meget hoj grad "spiller kønnet ud ” og bruger kønnet synligt og bevidst $i$ deres grundleggende identitetsarbejde, så er det $i$ hojere grad $i$ den anden gruppe, at de konkrete oplevelser af uligheder og af, at konnet virker begrensende for alvor tager form.

Denne tese vil jeg afslutningsvis uddybe og konkretisere på baggrund af to forskningsresultater - for den forste gruppes vedkommende med fokus på kønnets betydning blandt gymnasieelever, og for den anden gruppes vedkommende belyst gennem unges forventninger til kommende familie og arbejdsliv.

\section{GYMNASIEUNGDOM OG KØN}

Harriet Bjerrum Nielsen og Monica Rudberg lavede i starten af 90'erne en undersøgelse af den norske gymnasieungdom (18-årige) (se Bjerrum Nielsen og Rudberg 1994A og 1994B). De fortxller bl.a. således om deres introducerende møde med gymnasieeleverne:

(..vi ble..)straks døpt "kjønnsrolledamene" og jentenes reaksjoner delte seg i to: Den ene gruppen foret oss straks med historier om dominerende og mannsjåvinisktiske gutter i klassen - "vi blir virkelig skuffa om dere ikke legger merke til deres skjulte herskerteknikker!”. Den andre gruppen hørte på oss med et høflig overbærende smil og lurte på hvordan i alverden vi ville kunne forstå noe som helst om moderne ungdom med et så anakronistisk begrep som kjønnsroller - "individuelle forskjeller er mye mer betydningsfulle ens hva slags kjønn vi har, ihvertfall på denne skolen", sa de. Naturligvis viste det (Bjerrum Nielsen \& Rudberg 1994B:1)

Det viste sig, at begge grupper havde ret. Bjerrum Nielsen og Rudberg sammenfatter analysen af forandringerne af kønsidentitetet og kønsrelationerne på følgende måde (1994A:139 og 1994B:4).

- Kønnet er blevet meget mere synligt i en offentlig verden (her: klasserummet). Det ses $\mathrm{fx} \mathrm{i}$, at meget tætte og kropslige veninderelationer mellem pigerne (holde $\mathrm{i}$ hånden og "plukker i hverandres hår i positurer som mest av alt minne om avlusende apemødre"). Det foregår nu i fuld offentlighed - ja, det demonstreres nærmest foran et publikum. Dette i modsætning til tidligere, hvor sådanne intense veninderelationer hovedsagelig foregik i en lukket værelseskultur. Tendensen til at spille kønnet ud i offentligheden ser Bjerrum Nielsen og Rudberg også i en meget åben og synlig omgang med tamponer og menstruationsbind.

- Der er en øget polarisering mellem piger og drenge. Det ser ud til, at piger og drenge har forskellige meninger ikke kun om ligestillingsemner, men også fx om miljø, indvandrere og litteraturanalyser. Diskussionerne og stemningen betegnes som en regulær kønskamp. Samtidig understreger de unge dog, at disse "offentlige holdningsforskelle" ikke betyder noget for om de privat kan være venner eller kærester.

Kønnet har altid spillet en central rolle i de unges identitetsarbejde, men har fået en meget mere fremtrædende og synlig rolle. Bjerrum Nielsen og Rudberg viser, at også det seksuelle køn (fx i form af meget stramtsiddende tøj og et intens kæleri i fuld offentlighed) er meget tydelig i pigernes adfærd på en af de undersøgte skoler, men ikke på den anden, mere traditionelle skole. Undersøgelsen viser lige som den danske medborgerundersøgelse, at der er en stor 


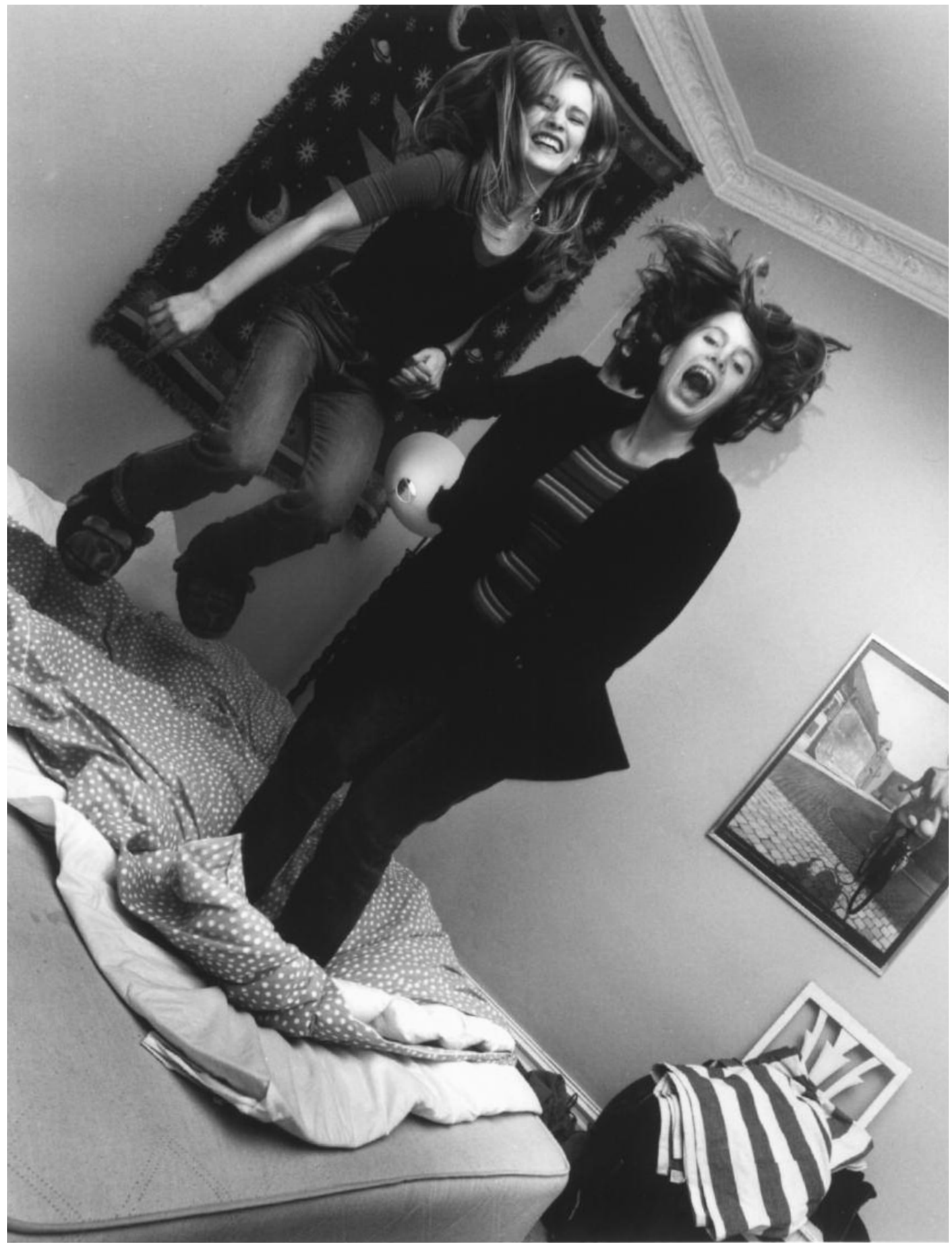

Foto: Oscar Mattsson, Mira/2. maj 
holdningsmæssig polarisering blandt pigerne og drengen. Det interessante er dog, at det her understreges, at holdningsforskelle og intense diskussioner tilsyneladende kan forenes med venskaber og flirt.

Relaterer vi dette til spørgsmålet om ligestilling mellem kønnene, er det afgørende, at politikken hverken direkte eller indirekte signalerer en afstandtagen eller fordømmelse af disse processer $\mathrm{i}$ de unges kønsidentitetsarbejde. Den meget synlige og kontante forholden sig til kønnenes forskelligheder blandt de unge kan givetvis provokere "kønsrolledamer" og feminister, ligesom en "missionsk" feminist kan provokere de unge!

Men det er også vigtigt at bemærke, at denne "nye" mere direkte forholden sig til kønnet ikke ser ud til at hænge sammen med, at de unge tager afstand fra ligestillingspolitikken. Bjerrum Nielsen og Rudberg viser således, at selv de mest aktive, højttalende og selvhævdende gymnasiepiger er kvindebevidste, men med en vis ironisk distance. Og selv om ligestillingskampen mest opfattes som mødrenes projekt, så ligger den fortsat som en præmis for pigernes identitetsarbejde og for det kvindeliv, de er villige til at acceptere.

\section{FORVENTNINGER TIL ET KOMMENDE ARBEJDS- OG FAMILIELIV}

Kun fremtiden vil vise, om de politiske holdningsforskelle blandt de unge fastholdes også i kommende livsfaser. Og kun fremtiden vil vise, hvilken betydning disse eventuelle holdningsforskelle vil få for relationen mellem kønnene. For selv om jeg har stillet spørgsmålstegn ved omfanget af den kulturelle frisættelse, så er der ingen tvivl om, at pluraliteten og mangfoldigheden af værdierne i dag er blevet større. Sagt på en anden måde så formoder jeg, at politiske holdningsforskelle blandt de unge i dag har en mindre betydning end fx i den politiserede og mobiliserede velfærdsgeneration. Måske vil fremtidens familier kunne rumme en langt større politisk bredde og pluralitet end det fx har været tilfældet i tidligere generationer. Men hvordan ser de unges forventninger ud til fremtidige relationer mellem kønnene?

En undersøgelse, foretaget af Birgitte Simonsen fra Roskilde Universitetscenter viser, at de unge kvinder og mond har meget forskellige forestillinger om det kommende arbejds- og familieliv. Birgitte Simonsen har i ungdomsforskningsprojektet "Konsekvenser af det husmoderløse samfund" interviewet 16-19 årige unge kvinder og mænd.

Birgitte Simonsen begrunder interessen for denne gruppe af unge med, at det er den første generation, der er vokset op i familier uden en husmoder. Et af hovedspørgsmålene er at undersøge, hvordan frigørelsen fra denne klassiske patriarkalske familieform påvirker de unges forventninger til egen familie- og arbejdsliv. Birgitte Simonsens undersøgelse viser bl.a., at denne frigørelse fra det traditionelle kønsrollemønster i familien har påvirket de unge kvinder og mænd forskelligt. De unge kvinder har mere eller mindre givet afkald på forsørger- husmoderrelationens stabilitet. De unge kvinder er orienteret mod at skaffe sig en placering på arbejdsmarkedet, så de bliver i stand til at forsørge sig selv. Hvis dette ikke lykkes er det den statslige og ikke den $x$ gteskabelige forsørgelse de orienterer sig mod. De unge mænd holder mere end de unge kvinder fast i forsørger-husmoderrelationen. De ser sig selv placeret i forsørgerrollen og orienterer sig bl.a. som følge heraf kraftigt mod en stabil placering på arbejdsmarkedet (Simonsen 1993 og 1994).

\section{FORSLAG TIL EN DIFFERENTIERET}

\section{LIGESTILLINGSSTRATEGI FOR DE UNGE}

På baggrund af ovenstående vil jeg foreslå en differentieret ligestillingsstrategi for de unge, der tager hensyn til de to grundlæggende tendenser blandt de unge, der fungerer side om side. 


\section{AT “SPILLE KØNNET UD” I FULD OFFENTLIGHED}

(primært de helt unge omkring 15-20 år)

Fokus på de unges orientering mod kønsidentitet og skabelse af kvinde- og manderoller. Det er mere end tidligere både tilladt og muligt at gøre kønnet meget synligt. Det benytter de unge sig i vid udstrækning af. De sætter fokus på autonomi og selvrealisering, som har et stort spillerum i det moderne samfund. Det er afgørende, at de unge ikke oplever ligestillingspolitikken som begrænsende for deres udfoldelsesmuligheder på dette område. Problemerne opleves sjældent som ligestillingsproblemer, og man når ikke gruppen med et ensidigt fokus på uligheder, men snarere ved at udvikle en aktiv og dialog-orienteret politik, der spiller med på kønnets centrale og aktive rolle i de unges identitetsarbejde.

\section{DEN “KØNNEDE” MODSÆTNING MELLEM ARBEJDE OG FAMILIELIV} (primært de "voksne unge" mellem 20-30 år)

I livsafsnittet mellem 20-30 år færdiggør de unge ofte deres uddannelse, de får sandsynligvis lønarbejde og de stifter muligvis familie og får børn. Det er en "fortættet" livsfase med afgørende valg for fremtiden. Køn spiller en stor rolle og afgørende rolle. Det er bl.a. i dette livsafsnit, at forventningerne til fremtiden skal omsættes til brugbare muligheder og praksis. Udfordringen for ligestillingspolitikken er her, at formulere en nærværende og aktiv politik. Fx må situationen som "nye kønnede" individer i både familie og på arbejdsmarkedet være synlig i en ligestillingsstrategi, der i forhold til denne gruppe fx kunne betone:

- kønsbestemte uligheder i uddannelsessystemet (hierarkier, rollemodeller, indhold)

- kønsbestemte uligheder på arbejdsmarke- $\operatorname{det}$ (kønsarbejdsdeling, hierarkier, lønforskelle, arbejdspladskultur)

- kønsbestemte uligheder i familie (arbejdsdeling, forældreroller og omsorgsforpligtelser)

\section{OPSAMLING}

Generelt i befolkningen og også blandt de unge er der en udbredt enighed om, at der finder en diskrimination af kvinder sted. I forlængelse heraf mener medlemmerne i $\mathrm{LO}$, at fagforeningen bør prioritere ligestillingen mellem kønnene som et af de helt centrale områder. Hvor de unges holdning til ligestilling mellem kvinder og mænd ikke adskiller sig fra de andre generationer, forholder det sig anderledes, hvis vi ser på holdningen til lighedsdimensionen i velfærdsstaten. Der er her tale om en markant polarisering, hvor vi i den ene pol har de unge mænd, der udtrykker en individualistisk og markedsorienteret holdning, og i den anden pol de unge kvinder, der støtter markant op omkring en offentlig omsorgsorientering. I forklaringen på denne polarisering mellem kønnene har jeg lagt vægt på samspillet mellem på den ene side det moderne samfunds "kulturelle frisættelse" af individerne, og på den anden side de sociale realiteter og brugbare muligheder, som de unge støder på, fx i overgangen til deres voksenliv. Det er min tese, at denne grundlæggende modsætning mellem forventninger og muligheder påvirker de to køn forskelligt.

På baggrund af ovenstående har jeg argumenteret for en differentieret og dialogorienteret ligestillingsstrategi, der tager hensyn til de forskelligheder, modsætninger og muligheder, som de unge møder i det moderne samfund. Brugbare ligestillingsstrategier må for det første tage hensyn til, at der blandt de unge er en tendens til at "spille konnet ud" $i$ fuld offentlighed (især blandt de "helt unge" omkring 15-20 år). Dette lægger op til en aktiv og dialogorienteret ligestillingspolitik, der er åben over 
for kønnets centrale rolle i de unges identitetsarbejde. For det andet er der en tendens til fortsat at genskabe den "kønnede" modsetning mellem arbejde og familieliv (især blandt de "voksne unge" mellem 20-30 år). Dette stiller krav om en nærværende politik, der er åben over for både de unge kvinder og de unge mænds position som "kønnede" individer, der er ved at etablere en position både i familien og på arbejdsmarkedet.

\section{LITTERATURLISTE}

- Andersen, Johannes, Christensen Ann-Dorte, Langberg Kamma, Siim Birte og Torpe Lars (1993) Medborgerskab. Demokrati og politisk deltagelse. Herning: Forlaget Systime.

- Andersen, Johannes \& Torpe Lars (eds.).1994. Demokrati og politisk kultur. Rids af et demokratisk medborgerskab. Herning: Forlaget Systime.

. Bild Tage m.fl. (1992a) Sikke nogen typer... Rapport over interviewundersøgelse blandt medlemmer af LO-forbundene. Aalborg Universitet:Carma.

- Bild Tage m.fl. (1992b) Follesskab og forskelle. Sammenfatningsrapport fra APL-projektet. Aalborg Universitet:Carma.

- Bild Tage og Madsen Morten (1994) De unges syn på arbejdsliv og politik. Analyse på baggrund af APL-datamaterialet. Aalborg Universitet:Carma og Institut for Statskunskab, KU.

- Borchorst Anette og Christensensen (1996)

“Kønspolarisering og velfærdsstat”, i: Dansk Sociologi nr. 1, side 110-17.

. Christensen Ann-Dorte (1994) "Køn, ungdom og værdiopbrud", i: Andersen \& Torpe (eds.)

Demokrati og politisk kultur. Rids af et demokratisk medborgerskab.Herning: Forlaget Systime, side 175-211.

- Christensen Ann-Dorte (1997) "De politisk kulturelle betydninger af køn", i: Christensen,

Ravn og Rittenhofer (red.) Det kønnede samfund. Forståelser af kon og social forandring,

Aalborg: Aalborg Universitetsforlag

- Hansen Erik Jørgen (1995) En generation blev voksen. Socialforskningsinstituttet, Rapport 95:8. - Højgaard Lis (1996) Køn og Løn. En analyse af virksombedskultur og lonforskelle mellem kvinder og mond i fire private virksombeder. København: Samfundslitteratur og Ligestillingsrådet. - Jørgensen Henning m.fl. (1992) Medlemmer og meninger. Rapport over sporgeskemaundersogelse blandt medlemmer af LO-forbundene. Aalborg Universitet:Carma.

- Kvinder \& Mrnd (1995) Arbejdsmarkedsstyrelsen, Danmarks Statistik og Ligestillingsrådet.

- Nielsen Harriet Bjerrum og Monica Rudberg (1994A) Psychological Gender and Modernity, Oslo: Scandinavian University Press.

- Nielsen Harriet Bjerrum og Monica Rudberg (1994B) Jenter og Gutter i forandring? Freia Tekst nr. 16, 1994

- Simonsen, Birgitte (1993) Unges forhold til arbejdsliv og forsørgelse. Konsekvenser af det husmoderlose samfund. Roskilde Universitetscenter, EVUgruppen: Rapport 2.

- Simonsen, Birgitte (1994) Unges forhold til familieliv og kønsroller. Konsekvenser af det husmoderlose samfund. Roskilde Universitetscenter, EVU-gruppen: Rapport 3.

- Siim, Birte (1994) Køn, medborgerskab og politisk kultur, i Andersen \& Torpe (eds.). Demokrati og politisk kultur. Rids af et demokratisk medborgerskab. Herning: Forlaget Systime, side125-175.

\section{NOTER}

1. Artiklen er skrevet på baggrund af et oplæg til Udvalget for det fremtidige ligestillingsarbejde.

Resume af artiklen kommer til at indgå i udvalgets beretning.

2. Medborgerundersøgelsen er lavet af en gruppe forskere primært fra Aalborg Universitet. Undersøgelsen bygger på en spørgeskemaundersøgelse, hvor et representativt udsnit af den danske befolkning blev interviewet i 1990 - dels om deres politiske deltagelse og dels om deres politiske holdninger. Kønsaspektet står centralt i begge analyser. Medborgerundersøgelsen er afrapporteret i to bøger: Johannes Andersen m.fl. (1993) og Andersen \& Torpe (red.) (1994) (se litteraturliste)

3. Dette udelukker ikke, at andre - mere kvalitativt orienterede undersøgelser - kan vise noget om de helt unges politiske forventninger og socialisering. Jeg understreger blot, at kvantitative undersøgelser bedst egner sig til konkret at spørge om, hvad folk har gjort, og hvilken mening de har (ikke hvad de tror, de kommer til at mene). Det indebærer, at det nødvendigvis skal være unge, der har en vis erfaring med politisk aktivitet og politiske diskussioner.

4. Denne centrale forskel mellem velfærdsgenerationen og 80'er-generationen hænger sammen med, at vi i 90'erne har bevæget os i retning af et tilsku- 
erdemokrati-samfundet er gennemorganiseret, men der er - sammenlignet med 70'erne og 80'erne - en langt mindre politisk aktivitet. Deltagelsen er blevet meget enkeltsags- og ad.hoc.orienteret, og kun få deltager aktivt i mere forpligtende politiske fællesskaber som politiske partier og sociale bevægelser.

5. Den mere præcise betegnelse for LO-undersøgelsen er forskningsprojektet om "Arbejdsliv og Politik set i et lønmodtagerperspektiv" (APL-projektet). En af projektets centrale konklusioner er, at den klassiske arbejderkultur er på retur. Der har i stedet udviklet sig en ny medlemskultur, der ikke lægger så meget vægt på højere løn, men mere på et meningsfuldt arbejde og egne udviklingsmuligheder. Undersøgelsen er afrapporteret i tre rapporter: Henning Jørgensen m.fl. (1992); Tage Bild m.fl. (1992a) og Tage Bild m.fl. (1992b). Endelig findes der en særlig analyse af de unge LO-medlemmer i Bild \& Madsen (1994) (udførlige referencer fremgår af litteraturlisten).

6. Det betyder ikke, at den sociale arv er forsvundet. Tværtimod. Fx dokumenterer Erik Jørgen Hansens undersøgelser fra Socialforskningsinstituttet, at der fortsat er en tæt sammenhæng mellem social oprindelse og social placering, som primært formidles gennem forskelle i uddannelsesniveau. Undersøgelserne viser også, at denne tendens er mere markant for kvinder end for mænd - altså at der er et samspil mellem køn og klasse. Erik Jørgen Hansen (1995).

7. Denne meget summariske præsentation af værdiopbrud og modernitet bygger især på Thomas Ziehe og Anthony Giddens. Disse forskere samt relationen til de unge i dag er diskuteret udførligt i Ann-Dorte Christensen 1994 (se litteraturliste)

\section{SUMMARY}

This article discusses the attitude of the young generation towards the question of equal opportunities and social equality in the welfare state. There is a rather large polarization between young women and men as regards their attitudes towards the welfare state. While young women support collectivism and public care, young men express more individualistic, neo-liberal attitudes. But, this polarization is apparently not to be found in the attitudes towards equal opportunities policies: both young men and young women agree, for instance, that discrimination against women does take place.

In the second part of the article I argue that it is necessary to develop an active and differentiated equal opportunities strategy for young people. One the one hand, there is a tendency among men and women in their early youth (15-20 years) to express their gender explicitly in public. This demands a $d y$ namic and culturally offensive policy. On the other hand, men and women in their later youth (20-30 years) encounter and negotiate more or less traditional gender relations in the labour market and the family. This demands an attentive and socially aware policy, reflecting the positions of young women and men as gender-specific individuals on their way to create an adult life both in their families and on the labour market.

Ann-Dorte Christensen

lektor, Ph.D.

FREIA, AAU 